\title{
Widowhood Practice in Eastern Nigeria: A Comparative Study of Imo and Anambra States
}

\author{
Bentina Alawari Mathias ${ }^{a}$
}

\begin{abstract}
Marriage is one of the valued institutions in the traditional African society. Incidentally, it has its own challenges. When a young man or woman gets to a certain age and he/she is not married, society frowns at it. Thus, many couples enter into marriage relationships with a lot of excitements and expectations. However, losing one's spouse to death robs one of all these excitements and expectations and exposes the bereaved spouse to some dehumanizing challenges. These challenges are mostly experienced by women in the Eastern Region of Nigeria. These women are subjected to dehumanizing practices which are socially accepted in the region. This paper attempts a comparative study of some of the practices imposed on widows in Eastern Nigeria. A sample of 200 participants was purposively selected from two states in the Eastern Region of Nigeria. The study adopted the qualitative research method. Thus, the analysis was made using descriptive method. The study showed that these inhuman traditional practices in Eastern Nigeria are initiated and perpetrated by the kinsmen (Umunna and Umuada). It also showed that the widowhood treatment is meted out on all widows, but the severity or less severity of these treatments are dependent on the socio-economic and other attributes of the widow. Finally, recommendations were made, which include the need to protect the fundamental rights of widows and their children.
\end{abstract}

\section{Keywords}

Marriage, rituals, rights, widow, widower

Marriage is a fundamental aspect of the society, hence the family that emerges through marriage processes is a microcosm of society (Iffih and Ezeah 2010). Iffih and Ezeah (2010) further defined that marriage is a durable union between one or more men and one or more women sanctioned by society. Marriage unites and brings peace and joy to the society. However, marriage has its associated challenges which include childlessness incompatibility among the spouses and losing one's spouse.

Of all the challenges, the death of one's spouse is usually a traumatic and disorganizing experience. For many women in the contemporary Nigerian society, losing a husband is almost like the end of the world (Amasiatu 2012). Whereas the man does not have much difficulty in remarrying when the wife dies, the woman on the other hand faces a myriad of social stigmas, traditional harassments, and maltreatment by in-laws who should actually be protecting her and her children. The word "widowhood" has variety of definitions in sociological literature. Edekobi (2000) defined widowhood as the condition that follows the death of one of the partners in a marriage. A widow is

\footnotetext{
aNnamdi Azikiwe University, Awka, Nigeria

Correspondent Author:

Bentina Alawari Mathias, Department of Sociology/Anthropology, Nnamdi Azikiwe University, Awka, Nigeria

E-mail: mathiasbentina@gmail.com
} 
any female person married under native law and custom or under the marriage act or any other law recognized in Nigeria whose husband has died and has not remarried (The prohibition of infringement of a widows/widower's Fundamental Rights Law 2001 Section 2 cited in Amasiatu 2012). While the widower on the other hand is a man who has lost the wife by death and has not remarried.

Research has shown that there are approximately three times as many widows in any society (Eshleman 1974). Eshleman (1974) attempted some explanation. He held that in many cases, the males culturally marry females who are younger than themselves. With the demographic theory of life expectancy at birth which is shown to be 74.3 for females and 66.8 for males by the time he conducted the study, females would live on the average 16.5 more years compared with 13 for males. Since demography has not shown any changes in these differentials, one can then conclude that there are more widows in the society than widowers. Besides, it must be remarked that males do remarry after the deaths of the spouse, while widows very often do not remarry, especially when they have children out of the marriage. They decide to remain with their children and more often suffer inhuman treatments in the hands of the relatives of their husband (Edekobi 2000).

Discrimination against women has particularly been serious in the case of widowhood. However, some discrimination against womanhood is reduced due to the forces of social change such as education, religion, and changes in values of society. But still women usually find themselves without inheritance rights and being subjected to frightening and dehumanizing widowhood rights (Onyekuru 2011).

Idialu (2012) argued that the Nigerian legal system recognizes a dual system of marriage both of which are mutually exclusive. These are "Statutory Marriage" and "Marriage Under Customary Law". The Nigerian family law which permits certain widowhood practice is discriminatory and oppressive to women vis-à-vis their male counterpart. On the other hand, the customarily married woman has more disadvantages than the statutory married woman. They are of the view that the fate of the widow is a direct consequence of the nature of marriage she contracts and the rights she accrues to herself thereof. It is also worthy to note that although statutory law and even Islamic law provide for women's capacity and rights of inheritance following the death of their spouse, in practice, it is not so. This is because of the customary law of succession. It is entrenched in Nigeria customary law that widows have no capacity to inherent assets following the death of their spouse. One of the reasons for this is that there is no concept of co-ownership of property by couples in the traditional Nigerian societies. In many traditions, after the husbands' death, his male relations take possession of the deceased valuables. The widow who is in the midst of mourning is usually powerless to resist this. To provide a form of social security, widows are traditionally inherited by male relatives of the deceased in most groups in Nigeria (Onyekuru 2011). Very often this practice is without the consent of the widow. Thus, when she refuses, she is accused of being responsible for her husband's death. This also earns her various dehumanizing treatments.

The plights of widows are made worse by these humiliating and dehumanizing rites. These rites are not uniform throughout the country.

It is worthy to note here that the Nigerian Constitution has some provisions for the protection of widows. In the 1999 Constitution of the Federal Republic of Nigeria, Chapter 4, the Fundamental Human Right provides for equality of rights, obligations, and opportunities to every citizen of Nigeria. Also entrenched in the constitution is the Widows' Rights:

(1) Not subjected to inhumane, humiliating, or degrading treatment;

(2) Right to remarry or make choice;

(3) Right to inheritance. 
In addition to this, the Enugu State House of Assembly on March 8, 2001, enacted a law that makes it unlawful to infringe the fundamental rights of widows and widowers and for other related matters. The law states that no person for whatever purpose or reason shall compel a widow or widower as follows:

(1) Shave the hairs on the head or any other part of the body;

(2) Sleep either alone or on same bed or be locked in a room with corpse of the husband;

(3) Not to receive condolence visits from sympathizers during the period of mourning;

(4) To be remarried by a relative of the late husband;

(5) To sit on the floor or be naked during any period of the husband's burial rite;

(6) To drink the water used in washing the corpse of the husband;

(7) To weep and wail loudly at intervals at anytime after the death of the husband except at one's own volition or involuntary action;

(8) To remain in confinement after the death of the husband for any given period;

(9) To vacate the matrimonial home;

(10) To do any other thing which contravenes the fundamental rights entrenched in the constitution or is degrading to the person.

Furthermore, on November 26, 2004, the Cross River State House of Assembly enacted a law that provides protection against domestic violence and maltreatment of widows. This law also makes it an offence punishable with $\$ 20,000$ (20 thousand naira) only fine and three years imprisonment for a widow to be maltreated. The maltreatment includes forcing a widow to drink water or any liquid used to bath her husband's corpse, shaving a widow's hair, throwing a widow out of her matrimonial home or denying her inheritance rights, forcing her to wear certain clothes or subjecting her to any ordeal or unpleasant and offensive tradition or custom. This law allows the police to arrest an offender without an arrest warrant (Civil Resource Development \& Documentation Centre [CIRDDOC] 2008).

However, despite all these laws in the Southeast Nigeria, widows in the Eastern Nigeria are still subjected to dehumanizing treatments. In most societies in Anambra and Imo States of Nigeria, there are set rules professed by tradition, most of which does not tally with the widows life style. These traditions constitute a burden and a plight for the widows. Some of these cultural practices which widows are required to observe for a certain period of time are:

(1) Restriction on clothing, feeding, and movement;

(2) Seclusion or isolation from the public;

(3) Forceful shaving of hair;

(4) Prohibition from bathing;

(5) Reutilized crying;

(6) Disinheritance of husbands property in most cases;

(7) Keeping mute throughout the funeral period;

(8) Cleansing rites;

(9) Excessive, prolonged, and forced mourning period;

(10) Remarrying the brother or relative of the husband.

The widow in some cases is suspected of being responsible for the husband's death, no matter the cause and reason for such death. As a result, she is made to prove her innocent by following some rigorous process of absolution. This may take the form of forcing the widow to drink the water used in washing her late husband's corpse as a way of exonerating her from the accusation or suspicions that she killed her husband. This is the worst which the widow is childless. In such case, she may be left alone with the husband's corpse (CIRDDOC 2004).

This study therefore attempts to compare the widowhood practice in Imo and Anambra States of Nigeria. 


\section{OBJECTIVES OF THE STUDY}

The specific objectives of this study include:

(1) To examine the experiences of widows in Imo and Anambra States;

(2) To examine the views of widows in Imo and Anambra States toward certain cultural practices which they are subjected to at the death of their husband;

(3) To find out if widowhood treatment varies according to socio-demographic and other related variables in Imo and Anambra States;

(4) To suggest ways of eliminating all harmful and dehumanizing widowhood practices in Imo and Anambra States.

\section{THEORETICAL ORIENTATION}

This study is anchored in equity theory. Equity theory is one of the middle range theories popularized by Robert Merton in 1968. The idea of middle range in theorizing in sociology was certainly not borne out of a desire on the part of Merton to castigate the insightful contributions of the classical sociologist. Merton elaborately made this clear when he pointed out the functions of the classics of sociology (Merton 1968). The equity theory which is particularly useful in the study of industrial sociology can be applied in various other sociological studies. The equity theory is built on the assumption that social beings have an inherent tendency toward comparing their situations with those of significant others, that is other people who they see as similar in most respects to themselves. Such comparison invariably produces a feeling of satisfaction or dissatisfaction as the case may be. In fact, people usually use such evaluations to measure their benefits from the social group or organization $v i s-\grave{a}$-vis their contributions and the rewards of other people with equal contributions.

In this case, people generally believe that equity should underline social group and to that extent people with equal contributions or stakes should benefit equally. A perception of inequality invariably breeds dissatisfaction (Okeibunor and Anugwom 2005).

In relation to this study, the widower and the widow are of equal status in the society, but they are perceived differently and treated differently. When a man's wife dies, the society rally round him to comfort him. They also encourage him to marry another wife who will take care of him and the children (if any). On the other hand, when a woman's husband dies, society accuse her of killing her husband and thus, subject her to a manner of dehumanizing treatment. This type of action breeds dissatisfaction and may engender conflict in the society (Dittrich and Carrel 1979).

\section{METHODOLOGY}

The study was conducted in Imo and Anambra States of Nigeria. The choice of these states was ideal for the study, because the selected states are the core Igbo-speaking states in the country where widowhood practices are held in extreme. The target population are widows who are 18 years and above. The selection of participants for the study was purposive and the study is largely descriptive in nature. The study employed qualitative method of data collection. In-depth interview was used to gather information from respondents.

\section{FINDINGS}

The demographic characteristics of the participants in Table 1 showed that $19.5 \%$ are between 18 and 27 years, $43.5 \%$ are between 28 and 37 years, $26 \%$ are between 38 and 47 years, $3 \%$ are between 48 and 57 years, while $8 \%$ are 58 years and above. Fifty percent $(50 \%)$ of the participants are residents in Anambra State and $50 \%$ are residents in Imo State. On the length of time they have been widows, $16 \%$ have been 
widows for $1-10$ years, $32 \%$ have been widows for $11-20$ years, $15 \%$ have been widows for 21-30 years, $21 \%$ have been widows for $31-40$ years, and $16 \%$ have been widows for 41 years and above. The religion affiliation of the participants showed that $96 \%$ are Christian while $4 \%$ are traditional African worshippers. None of the participants is a Moslem. This may be because Christianity and ATR (African Traditional Religion) are the dominant religions in the study area. In their educational qualification, $1 \%$ had no formal education, $44.5 \%$ had primary education, $52 \%$ had secondary education, while $2.5 \%$ had post secondary education. On occupation, $26 \%$ are civil servants, $44 \%$ are business women, $20 \%$ are petty traders, while $10 \%$ are house wives (see Table 1 ).

\section{THE VIEW OF WIDOWS TOWARD WIDOWHOOD PRACTICE IN IMO AND ANAMBRA STATES}

Below are the presentations of some of the experiences of selected widows in Anambra and Imo states.

\section{The Experiences of Widows in Imo State}

A childless widow in Imo State stated that she was beaten and tormented and finally thrown out of her matrimonial home by the Umunna (kinsmen). According to her, she was not allowed to participate in her husband's burial. She went back to her parents but they could not help her. This is because it is traditionally believed that childlessness is a curse. Another widow said that she suffered dehumanizing treatment because she refused to be married off to a brother in-law. As a punishment, all her husband's land and properties were taken away from her. One of the respondents, a 22-year-old widow said that her two children (aged two and five years) were forcefully removed from her, also all her husband's properties were also removed, because she told her father in-law that she would like to remarry.
Generally, in Imo State, widows mourn their husbands' death for a minimum of six months. This period is counted from the date the husband is buried. Immediately the husband is lowered to the grave, other older widows take her away and shave her hair, she is not expected to participate in the husband's funeral or receive any gift from visitors. She is kept in isolation. If the husband is a very young man, possible under 30 years, she will dress in black throughout the mourning period, but if the husband is elderly or a Christian, she dresses in white. She does not sit on a high raised chair. She sits either on the floor, mat, or kitchen seat if the husband is a first son or in possession of family property. The next of kin takes over the properties including the woman because she is regarded as one of the properties. However, if the widow has son(s), the property is shared between the son(s) and next of kin. Thus, if the son(s) cares/care to retain their mother they can do so by taking her as part of their share.

\section{The Experience of Widows in Anambra State}

A 26-year-old widow who had only one daughter when her husband died said that her husband's only brother collected all her husband's properties and the Umunna supported him because she does not have a son. Another widow said that her husband does not have any property because he was a civil servant. According to her, her husband depended on his salary. Thus, when the husband died, none of the relatives came to help her, instead, they were sure that she spent all that she had and all that sympathizers gave her on the funeral rites. After the burial, she was left to care for the children alone. Another widow whose son is a "Reverend Father" in the Roman Catholic Church popularly known as "Mama Fada" said that no discriminatory treatment was meted out on her. She shaved her hair because of her respect for her husband. She is mourning and wearing white because she loves her husband and she missed him. She will go to church after six months to celebrate the end of her 
Table 1. Demographic Characteristics of the Respondents

\begin{tabular}{|c|c|c|c|}
\hline Variables & Responses & Frequency & Percentage (\%) \\
\hline \multirow{5}{*}{ Age } & $18-27$ & 39 & 19.5 \\
\hline & $28-37$ & 87 & 43.5 \\
\hline & $38-47$ & 52 & 26 \\
\hline & $48-58$ & 6 & 3 \\
\hline & 58 and above & 16 & 8 \\
\hline Total & & 200 & 100 \\
\hline \multirow{2}{*}{ Place of residence } & Anambra & 100 & 50 \\
\hline & Imo & 100 & 50 \\
\hline Total & & 200 & 100 \\
\hline \multirow{5}{*}{$\begin{array}{l}\text { Length of time } \\
\text { being a widow }\end{array}$} & $1-10$ years & 32 & 16 \\
\hline & $11-20$ years & 64 & 32 \\
\hline & $21-30$ years & 30 & 15 \\
\hline & $31-40$ years & 42 & 21 \\
\hline & 41 years and above & 32 & 16 \\
\hline Total & & 200 & 100 \\
\hline \multirow{4}{*}{ Religious affiliation } & Christian & 192 & 96 \\
\hline & Moslem & - & - \\
\hline & ATR & 8 & 4 \\
\hline & Others & - & - \\
\hline Total & & 200 & 100 \\
\hline \multirow{4}{*}{ Educational qualification } & Nonformal education & 2 & 1 \\
\hline & Primary & 89 & 44.5 \\
\hline & Secondary & 104 & 52 \\
\hline & Post secondary & 5 & 2.5 \\
\hline Total & & 200 & 100 \\
\hline \multirow{4}{*}{ Occupation } & Civil servants & 52 & 26 \\
\hline & Business women & 88 & 44 \\
\hline & Petty traders & 40 & 20 \\
\hline & House wives & 20 & 10 \\
\hline Total & & 200 & 100 \\
\hline
\end{tabular}

mourning period. It is worthy to note here that this type of treatment is rear. It could be because of the respect that the Christian Community have for the clergy.

In general, widows shave their hair immediately their husband is buried. They do not come out during that period. They stay indoors for 12 days or more depending on the community which they belong to, they are not supposed to sleep even at night, they do not relate with anybody. Whatever they will eat will come through the back door or across the fence. They do not share anything with other members of their family including their bathing bucket, cooking utensils, etc.

\section{THE WIDOWS VIEW TOWARD THE DEHUMANIZING TREATMENT GIVEN TO THEM}

The widows' views toward the different dehumanizing 
treatments they are subjected to are the same in Imo and Anambra States. They are not happy with the way they are treated by in-laws when their husband died. A 26-year-old widow from Anambra State who is a graduate said that "It is a violation of human right". Another widow from Imo State said that a lot of widows have died shortly after their husband as a result of such treatments. An elderly widow from Anambra said that the approach which the in-laws use to collect their brother's properties is what creates misunderstanding between the widows and the families. According to her,

During her own time, the brothers in-law came around to help the widow to do some work like fetching firewood, cutting palm seeds, etc. Thus, with this cordial relationship when he came in the night to have sexual relationship with the widow, she will normally accept. However, now the approach is different. The approach is forceful and no woman will ordinarily accept such thing.

Generally, all the widows interviewed said that the way widows are treated in both Imo and Anambra States is very unfair. It is dehumanizing and it reduces the dignity of womanhood ironically, it is still the widows who shave other widow's hair, tell them to sit on the floor, and make sure that all the rites are performed.

\section{VARIATIONS IN CULTURAL PRACTICES AGAINST WIDOWS}

There is similarity between the cultural practices against widows in Imo and Anambra States. However, the socio-demographic status of the widow is an independent variable that causes variation in the way widows are treated. For instance, religion and especially Christianity reduces the harsh treatment on widows. Thus, when a man is a member of any of the Pentecostal denominations or the son or daughter is a reverend father or sister in the Roman Catholic Church, the society respect the widows of such men.

Occupation is another variable that causes variation on the cultural practice against widows. Women who are lawyers have fewer tendencies to be maltreated. This is because they know their rights and how to defend it. Also, no establishment whether public or private will allow a woman to be away for six month because she wants to mourn her husband and observe all the cultural rites. Thus, widows who are working will always have excuse to go back to work.

Age of the woman as well as age and sex of the children are another determinant of how a widow is treated. For the elderly widows, the kinsmen do not see them attractive for marriage. Widows who have grown-up sons especially if the sons are wealthy are protected by their children from some of the cultural rites.

Education has a role to play in the way widows are treated culturally. Educated women do not accept some of the cultural practices especially those that are dehumanizing. Very often they go to the court or any human right protection organization to seek for redress.

The socio-economic status of a man to a large extent affects how his widow is treated. If a man has land, estate, shares, cars, and money, the kinsmen always come around to take possession of these properties. However, if a man is poor and indebt before he dies, nobody comes to inherit the debts.

\section{WAYS OF REDUCING HARMFUL CULTURAL PRACTICES AGAINST WIDOWS}

The participants in this study suggested that awareness should be created among the titled men. The Ozo (titled men) should be made to know that widows are human being and should be treated thus. A widow who was crying all through the interview said that husbands should include in their will that their wives should not be maltreated when they die. Government 
should enact laws which will punish anybody however high placed who maltreats a widow.

\section{CONCLUSIONS}

Widowhood practice in Nigeria generally and in the Igbo land in particular is a clear illustration of gender inequality. This inequality is shown in the inhuman treatments and injustices meted on widow but are not meted on widowers. The relative larger number of widows in the society is caused by the tendency of women to outlive men and also the tendency to marry older men. Also, more men remarry when they lose their spouse than their women counterpart.

These inhuman traditional practices in Igbo land are initiated and perpetrated by the kinsmen (Umunna and Umuada) who are more concern with cleansing and absolving a widow most often insist on these rituals. The study showed that the widowhood treatment is meted out on all widows, but the severity or less severity of these treatments is dependent on the socio-economic and other attributes of the widow. The widow who is educated, who is a wage employed worker, or who resides in the urban area is more protected than the widow who is not educated and resides in the rural area. It also showed that widows that are Christian and who have male children are treated better than widows who are not affiliated to any Christian organization. The widows that suffer most are childless widows, very often they are labelled as "witch".

The Federation of Women Lawyers, government and non-governmental organizations have launched campaign against harmful widowhood practice. Some traditional rulers have also made laws that reduce the mourning period from one year to six months. Yet, widows are still been maltreated. The study therefore made the following recommendations.

(1) Women should be empowered with education at least to secondary school level. This will help to equip them with the knowledge of the fundamental rights;

(2) Traditional rulers and town unions should renounce and discard all offending widowhood rites which violate human rights in their areas;

(3) Women should encourage their husbands to write his will and deposit the same one with lawyers or banks to avoid falling into the wrong hands;

(4) Massive enlightenment should be carried out to educate widow on their human and legal rights especially in the rural communities and equally educate the Umuada and Umunna on the need to treat their fellow women and wives with respect and dignity.

\section{References}

Amasiatu, I. 2012. Legal Challenges to Christian Life With Emphasis on Marriage. Port Harcourt: Nebos Christian Services.

Civil Resource Development \& Documentation Centre (CIRDDOC). 2004. "A Law to Prohibit Domestic Violence Against Women and Maltreatment of Widows Law No. 10." Public Education Series 32:24-26.

—. 2008. "Reproductive Rights Are Human Rights." Pp. 11-16 in Proceedings of a National Tribunal on the Violation of Reproductive Health \& Rights of Women in Nigeria Public Education Series (No. 23). Enugu: Fourth Dimension Publishers (FDP).

Dittrich, J. and M. Carrel. 1979. "Organizational Equity, Perception Employee Job Satisfaction Absence \& Turnover Rate." Organizational Behavior and Human Performance 24(1):5-30.

Edekobi, A. C. 2000. "The Widow's Right in the Context of Fundamental Human Rights." Nnamdi Azikiwe University Journal of Sociology 1(2):18-26.

Eshleman, J. R. 1974. Family: An Introduction. Boston: Allyn and Bacon Inc.

Idialu, E. E. 2012. "The Inhuman Treatment of Widows in African Communities." Current Research Journal of Social Sciences 4(1):35. Retrieved (http://maxwellsci.com/print/ crjss/v4-6-11.pdf).

Iffih, B. N. and P. C. Ezeah. 2010. Sociology of the Family. Enugu: John Jacobs Publishers Ltd.

Merton, R. K. 1968. Social Theory and Social Structure. New York: The Free Press.

Okeibunor, J. C. and E. E. Anugwam. 2005. Sociological 
Theory: An Insight Into the Dominant View Points. Nsukka: Great AP Express Publishers Ltd.

Onyekuru, B. U. 2011. "Obnoxious Cultural Practices Associated With Bereavement Among People of South-East Geopolitical Zone of Nigeria." Journal of Emerging Trends in Educational Research and Policy Studies 2(5):355-360.

\section{Bio}

Bentina Alawari Mathias, Ph.D., associate professor, Department of Sociology/Anthropology, Nnamdi Azikiwe University, Awka; research fields: institutional analysis, gender studies, conflict and security studies, medical sociology, and international relations. 